\title{
JARINGAN SARAF TIRUAN BACKPROPAGATION UNTUK APLIKASI PENGENALAN TANDA TANGAN
}

\author{
Fani Widiastuti, Wilis Kaswidjanti, Heru Cahya Rustamaji \\ Program Studi Teknik Informatika, Fakultas Teknologi Industri \\ Universitas Pembangunan "Veteran" Yogyakrata \\ email : wilisk@upnyk.ac.id,
}

\begin{abstract}
Back propagation neural network is part of a multilayered feedforward neural network (MFN) which has been developed and reliable enough to solve the problem of approximation and pattern classification. Application of artificial neural network (ANN) in pattern recognition is one of the signature pattern recognition. Signature of each person are generally identical but not the same. This means that often a person's signature changes every time. This change concerns the position, size and pressure factors signature. Signature is the most widely used form of identification of a person. In general, to identify the signature is still done manually, by matching signatures at the time of the transaction with a valid signature. Therefore, we need a system that can analyze the characteristic signature making it easier to identify the person's signature. The research methodology used in the development of the system is a method Rappid Guidelines for Application Engineering (GRAPPLE), which only covers the design stage needs (Requirement Gathering), analysis (Analysis), the design (Design), and development (Development). This signature recognition process through several stages. First image through image processing stages, where the image will be used as the image of the gray / grayscaling. Once the image is converted into binary data by using thresholding. After going through the binary image processing, the data obtained will be the input value to the training process by using the backpropagation method. The results of the training will be used for the process of signature recognition. Image signatures used in this study were 80 image signatures from 10 respondents. The ratio between training data and testing data is 5:3. The test results show that the signature is able to recognize applications built with precision signature $84 \%$ of the tested signatures. Errors in the identification of signatures occur for several reasons, namely: the position of the signature, the image file is damaged, and the learning process is not maximized.
\end{abstract}

\section{Keywords: Neural Networks, Backpropagation, signature recognition}

Jaringan saraf tiruan backpropagation merupakan bagian dari jaringan multilayered feedforward neural (MFN) yang telah dikembangkan dan cukup handal dalam memecahkan masalah aproksimasi dan klasifikasi pola. Penerapan jaringan saraf tiruan (JST) dalam pengenalan pola salah satunya adalah pengenalan pola tanda tangan. Tanda tangan setiap orang umumnya identik namun tidak sama. Artinya tanda tangan seseorang sering berubahubah setiap waktu. Perubahan ini menyangkut posisi, ukuran maupun faktor tekanan tanda tangan. Tanda tangan merupakan bentuk yang paling banyak digunakan untuk identifikasi seseorang. Pada umumnya, untuk mengidentifikasi tanda tangan masih dilakukan secara manual yaitu dengan mencocokkan tanda tangan pada waktu transaksi dengan tanda tangan yang sah. Oleh karena itu, diperlukan sebuah sistem yang mampu menganalisa karakteristik tanda tangan sehingga mempermudah dalam mengidentifikasi tanda tangan seseorang. Metodologi penelitian yang digunakan dalam pengembangan sistem adalah metode Guidelines for Rappid APPlication Engineering (GRAPPLE), yang hanya meliputi tahap perancangan kebutuhan (Requirement Gathering), analisis (Analysis), desain (Design), dan pengembangan (Development). Proses pengenalan tanda tangan ini melalui beberapa tahapan. Pertama image melalui tahap image processing, dimana image akan dijadikan citra keabuan/ grayscaling. Setelah itu citra diubah menjadi data biner dengan menggunakan thresholding. Setelah melalui image processing maka data biner yang didapatkan akan menjadi nilai input untuk proses pelatihan dengan menggunakan metode backpropagation. Hasil dari pelatihan akan digunakan untuk proses pengenalan tanda tangan. Citra tanda tangan yang digunakan dalam penelitian ini sebanyak 80 citra tanda tangan yang berasal dari 10 responden. Rasio antara data training dan data testing adalah 5:3. Hasil pengujian tanda tangan menunjukan bahwa aplikasi yang dibangun mampu mengenali tanda tangan dengan ketepatan $84 \%$ tanda tangan yang diujikan. 
Kesalahan dalam identifikasi tanda tangan terjadi karena beberapa hal, yaitu : posisi tanda tangan, file gambar yang rusak, dan proses pembelajaran yang belum maksimal.

\section{Kata kunci : Jaringan Saraf Tiruan, Backpropagation, pengenalan tanda tangan}

\section{PENDAHULUAN}

Seiring dengan perkembangan teknologi saat ini, para ahli mencoba untuk menggantikan sifat kerja otak manusia dengan komputer ataupun aplikasi yang cerdas, sehingga diharapkan akan tercipta komputer atau aplikasi yang dapat berpikir selayaknya otak manusia yang dapat mengambil suatu keputusan sendiri dengan memperhatikan dan menimbang input/ masukan yang diberikan dengan melalui pelatihan atau pembelajaran. Hal inilah yang mendorong terciptanya Artificial Intelegence (Al). Yang salah satu cabangnya adalah jaringan saraf tiruan.

Jaringan Saraf Tiruan merupakan sistem pemrosesan informasi yang memiliki kemampuan pembelajaran terhadap data dan informasi yang diterima, kemampuan untuk memodelkan fungsi linear, komputasi paralel, dan mempunyai sifat mentolerir ketidakpastian (fault tolerance). Penerapan jaringan saraf tiruan sangatlah luas, diantaranya adalah dalam hal peramalan (forecasting), analisis data (data analysis), dan pengenalan pola. Penerapan jaringan saraf tiruan (JST) dalam pengenalan pola salah satunya adalah pengenalan pola tanda tangan. Tanda tangan setiap orang umumnya identik namun tidak sama. Artinya tanda tangan seseorang sering berubah-ubah setiap waktu. Perubahan ini menyangkut posisi, ukuran maupun faktor tekanan tanda tangan. Tanda tangan merupakan bentuk yang paling banyak digunakan untuk identifikasi seseorang. Pada umumnya, untuk mengidentifikasi tanda tangan masih dilakukan secara manual yaitu dengan mencocokkan tanda tangan pada waktu transaksi dengan tanda tangan yang sah. Tekstur citra tanda tangan yang unik pada setiap orang dapat dianalisis untuk diidentifikasi. Oleh karena itu, diperlukan sebuah sistem yang mampu menganalisa karakteristik tanda tangan sehingga mempermudah dalam mengidentifikasi tanda tangan seseorang. Sebuah tanda tangan dapat ditangani sebagai sebuah citra sehingga dapat dikenali dengan menggunakan aplikasi pengenalan pola pada pengolahan citra. Salah satu arsitektur dari jaringan saraf tiruan yang memiliki keakurantan dan kecepatan yang cukup tinggi adalah jaringan saraf tiruan backpropagation. Jaringan syaraf tiruan backpropagation dikenal sebagai salah satu bentuk dari jaringan syaraf feedforward lapis banyak yang handal dalam memecahkan masalah aproksimasi dan klasifikasi/ pengenalan pola. Dalam penelitian ini data yang digunakan merupakan sebuah citra gambar yang didapatkan dari hasil scanning.

\section{DASAR TEORI}

\subsection{Jaringan Syaraf Tiruan}

Pengertian jaringan saraf tiruan adalah sistem pemroses informasi yang memiliki karakteristik untuk kerja tertentu yang menyerupai jaringan saraf biologis (Fausett, 1994). JST telah dikembangkan sebagai generalisasi model matematika dari aspek kognitif manusia atau saraf biologis, yaitu didasarkan pada asumsi-asumsi bahwa :

1. Pemrosesan informasi terjadi pada elemen - elemen yang disebut neuron.

2. Sinyal-sinyal merambat di antara neuron melalui interkoneksi.

3. Setiap interkoneksi memiliki bobot yang bersesuaian yang pada kebanyakan jaringan saraf berfungsi untuk mengalikan sinyal yang dikirim.

Setiap neuron menerapkan fungsi aktivasi (biasanya tidak linear) pada masukan jaringan untuk menentukan sinyal keluarannya

\subsection{Backpropagation}

Jaringan saraf tiruan Backpropagation pertama kali diperkenalkan oleh Rumelhart, Hinton dan William pada tahun 1986. Kemudian Rumelhart dan Mc Clelland mengembang kannya pada tahun 1988. Algoritma Backpropagation untuk neural network umumnya diterapkan pada perceptron berlapis banyak (multilayer perceptrons). Perceptron paling tidak mempunyai bagian input, bagian output dan beberapa lapis yang berada di antara input dan output. Lapis di tengah ini, yang juga dikenal dengan lapis tersembunyi (hidden layers), bisa satu, dua, tiga dan seterusnya. Output lapis terakhir dari output layer langsung dipakai sebagai output dari neural network. Training pada metode Backpropagation melibatkan 3 tahapan, yaitu pola training feedfoward, penghitungan error dan penyesuaian bobot. Setelah dilakukan training, aplikasi jaringan hanya menggunakan komputasi tahapan pertama yaitu feedfoward untuk melakukan 
testing. Walaupun tahap training terhitung lambat, namun jaringan dapat menghasilkan output dengan sangat cepat. Metode Backpropagation telah divariasikan dan dikembangkan untuk meningkatkan kecepatan proses training. Walaupun satu lapisan jaringan sangat terbatas dalam pembelajarannya, jaringan dengan lapis banyak dapat memperlajari lebih banyak lagi. Lebih dari satu lapisan tersembunyi mungkin bermanfaat untuk beberapa aplikasi, namun satu lapisan tersembunyi sudah cukup.

\subsection{Arsitektur Backpropagation}

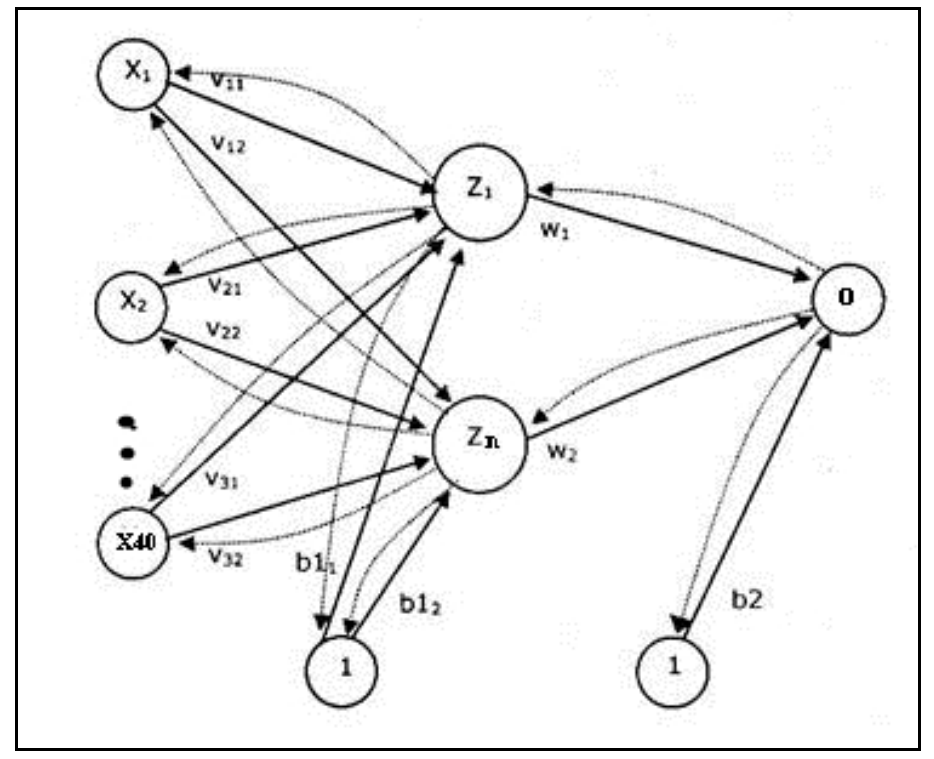

Gambar 1. Arsitektur Backpropagation

Jaringan saraf tiruan Backpropagation terdiri dari banyak lapisan (multilayer neural network), yaitu:

1. Lapisan masukan (Input Layer).

Lapisan masukan terdiri dari neuron - neuron atau unit - unit masukan, mulai dari masukan 1 sampai unit masukan $\mathrm{n}$.

2. Lapisan tersembunyi (Hidden Layer).

Lapisan tersembunyi terdiri dari unit tersembunyi mulai dari unit tersembunyi 1 sampai unit tersembunyi $p$.

3. Lapisan keluaran (Output Layer).

Lapisan keluaran terdiri dari unit - unit keluaran mulai dari unit keluaran 1 sampai unit keluaran $\mathrm{m}$.

Simbol n,p,m masing-masing adalah bilangan integer sembarang menurut arsitektur jaringan saraf tiruan yang dirancang.

\section{4 Tanda Tangan}

Tanda tangan adalah hasil proses menulis seseorang yang bersifat khusus sebagai substansi simbolik. Tanda tangan merupakan bentuk yang paling banyak digunakan untuk identifikasi seseorang.

Contoh-contoh tanda tangan setiap orang umumnya identik namun tidak sama. Artinya tanda tangan seseorang sering berubah-ubah setiap waktu. Perubahan ini menyangkut posisi, ukuran maupun faktor tekanan tanda tangan. Pada kenyataannya, perubahanperubahan tersebut dipengaruhi oleh waktu, umur, kebiasaan dan keadaan mental tertentu (Abbas, 1994). 


\section{METODE PENELITIAN}

Metode pengembangan menggunakan GRAPPLE dengan tujuan dapat menghasilkan sistem berorientasi objek dalam waktu yang singkat tanpa mengurangi kualitas sistem yang dibangun. GRAPPLE adalah sebuah pemodelan proses dalam pengembangan software yang menekankan pada aksi-aksi yang dilakukan pada sejumlah tahapan, setiap tahap akan menghasilkan produk kerja dengan bentuk yang berorientasi objek (Schmuller, 1999). Segmen yang terdapat dalam GRAPPLE tidak disusun dalam bentuk yang statis sehingga setiap segmen dapat dikerjakan berulang kali dengan urutan kerja yang tidak harus sesuai dengan urutan yang ada. Segmen-segmen yang digunakan dalam GRAPPLE mencakup analisis kebutuhan sistem, pengembangan model dan diagram, pembuatan kode hingga segmen instalasi dan evaluasi.

\subsection{Analisis (Analysis)}

Analisis merupakan proses untuk menganalisa hasil proses perencanaan kebutuhan (requirement gathering) yang dijelaskan dalam bentuk pemodelan sistem menggunakan diagram UML. Usecase diagram menggambarkan sekelompok usecase dan aktor yang disertai dengan hubungan diantaranya. Dalam perancangan sistem ini terdapat 2 aktor yaitu : admin dan user. Dan terdapat 7 usecase yang menerangkan kegiatan-kegiatan yang dilakukan software ini. Usecase diagram dari aplikasi ini dapat dilihat pada gambar 2 di bawah ini:

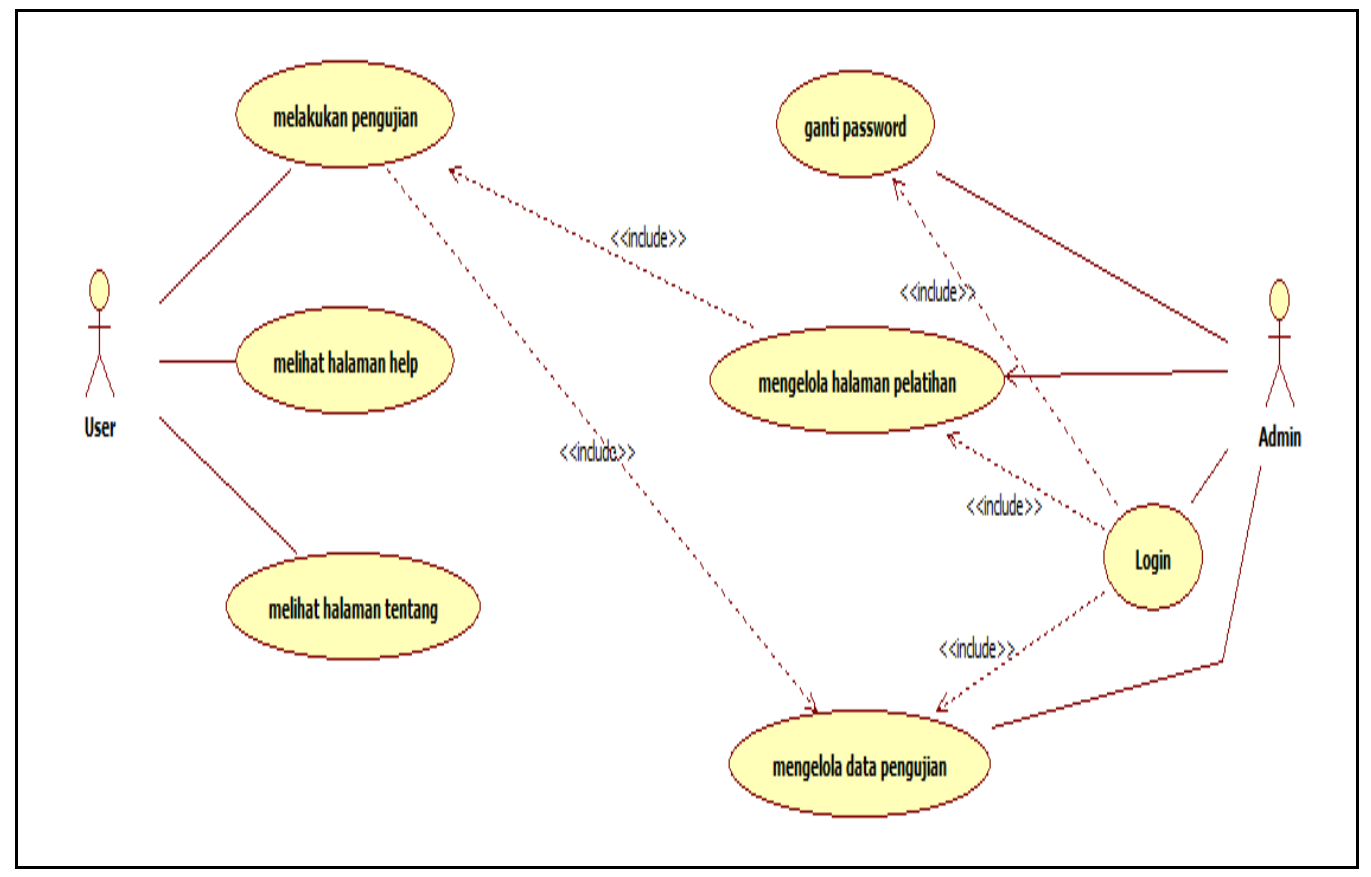

\subsection{Flowchart}

Gambar 2. Usecase Diagram

Bagan alir program (flowchart) merupakan rancangan yang menggambarkan alur data atau alur logika pemograman dari aplikasi yang akan dirancang, seperti proses perhitungan. Bagan alir program ini menggambarkan langkah-langkah kerja yang dijalankan oleh program dari mulai sampai program dihentikan. Flowchart induk dari aplikasi ini dapat dilihat pada gambar 3. 


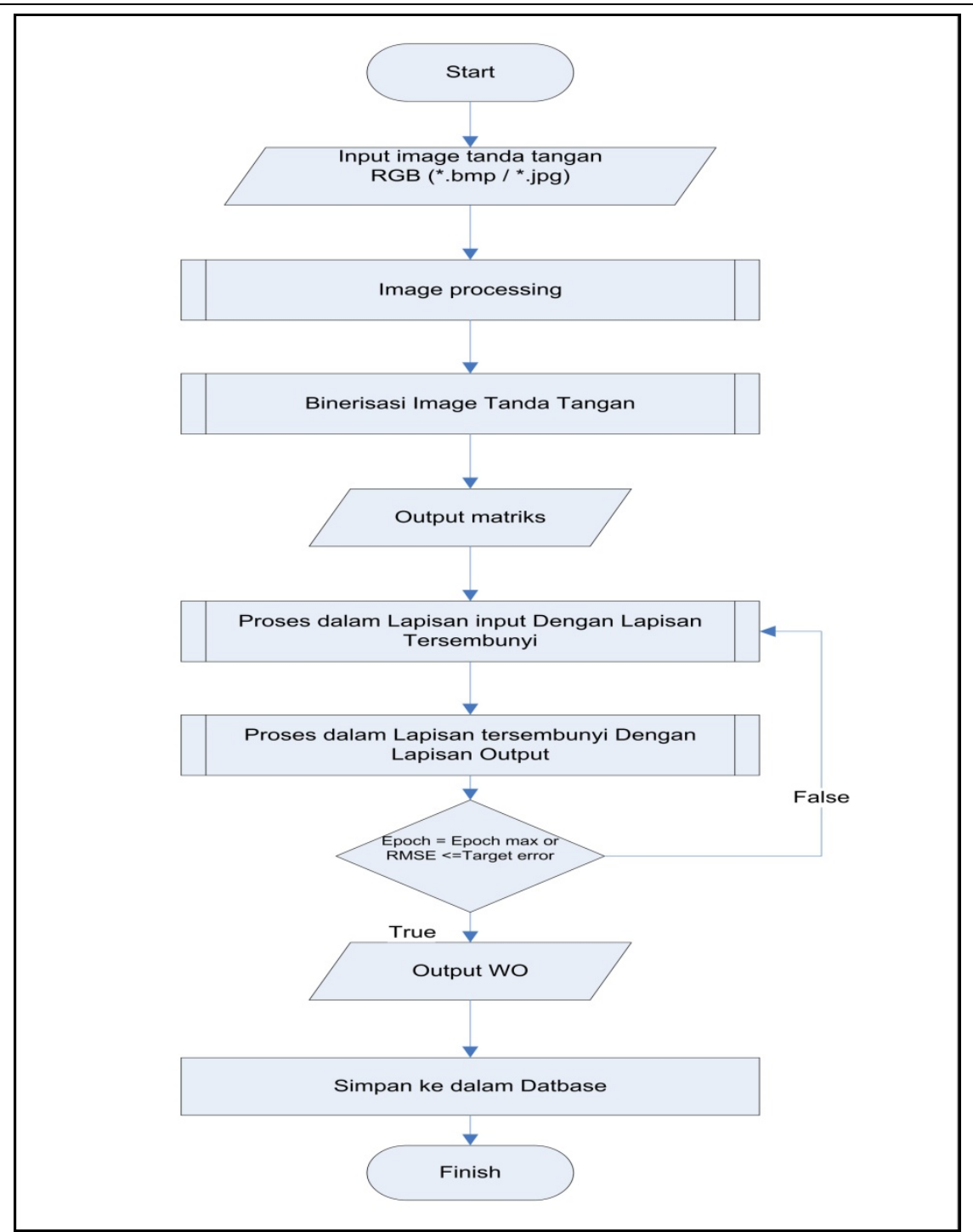

\section{Gambar 3 Flowchart Proses JST}

\section{HASIL DAN PEMBAHASAN}

\subsection{Aplikasi Pengenalan Tanda Tangan}

Aplikasi ini menampilkan form tertentu untuk pengenalan tanda tangan.

\section{Halaman Pelatihan}

Pada halaman pelatihan, admin dapat melakukan olah data mahasiswa. Terdapat fungsi simpan, edit, dan hapus data mahasiswa. Data mahasiswa terdiri dari NIM, nama, dan gambar tanda tangan. Selain dapat melakukan olah data, admin dapat melakukan proses pelatihan tanda tangan. Pada halaman ini terdapat fasilitas penggantian parameter pelatihan jaringan syaraf tiruan seperti learn rate, target error, maximum epoch. Hal ini dimaksudkan agar admin dapat melakukan percobaan-percobaan untuk meningkatkan kinerja dari jaringan syaraf tiruan. 


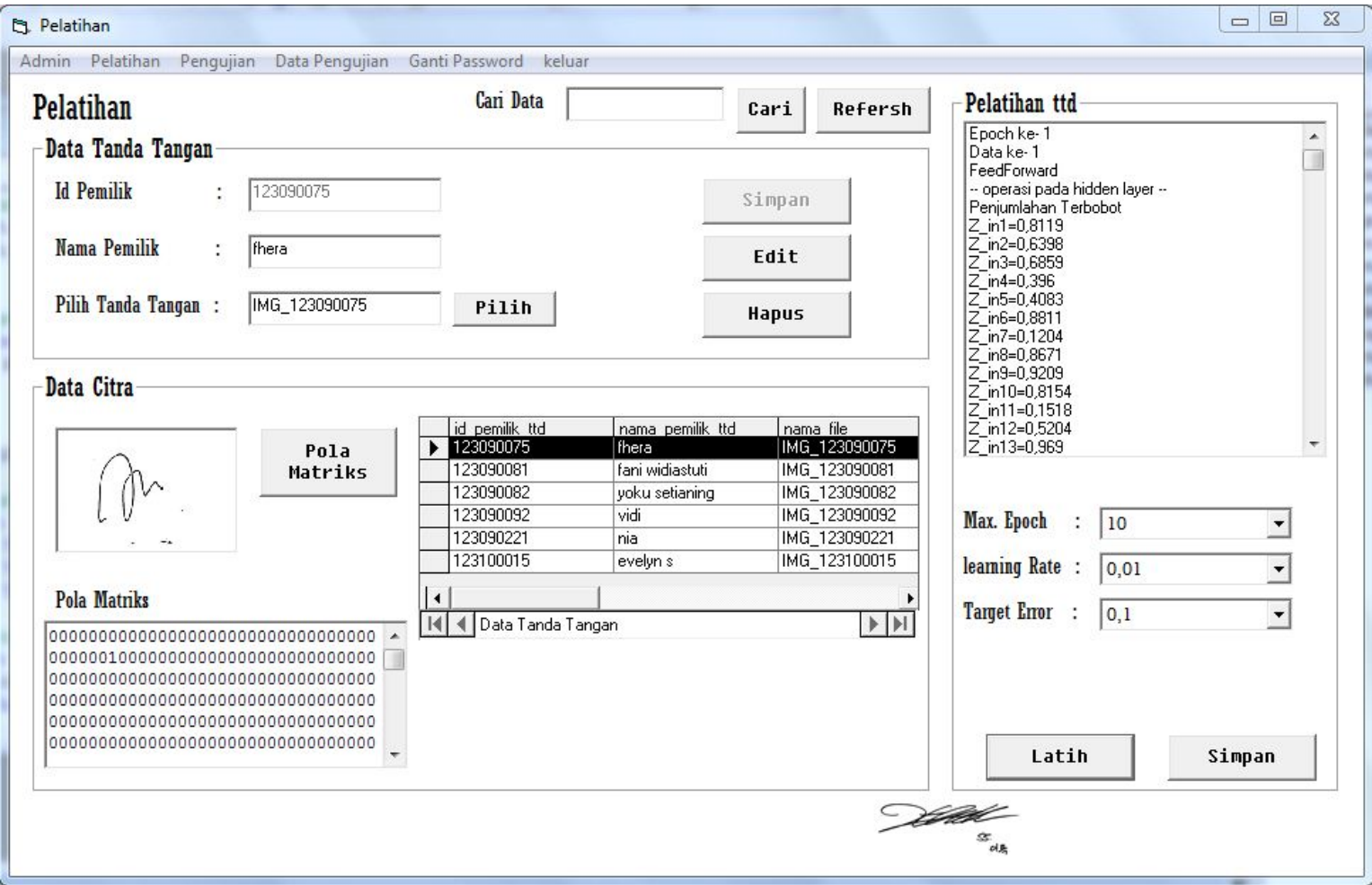

2. Halaman Pengujian

\section{Gambar 4.1 Halaman Pelatihan}

Pada halaman pengujian, user dapat melakukan pengujian tanda tangan dengan menginputkan tanda tangan dengan mengklik button "Select", setelah itu klik button "Pola Matriks" untuk mengubah citra ke dalam bentuk matriks, terakhir klik button "Uji". Maka akan muncul hasil dari pengujian berupa nim pemilik tanda tangan dan nama pemilik tanda tangan.

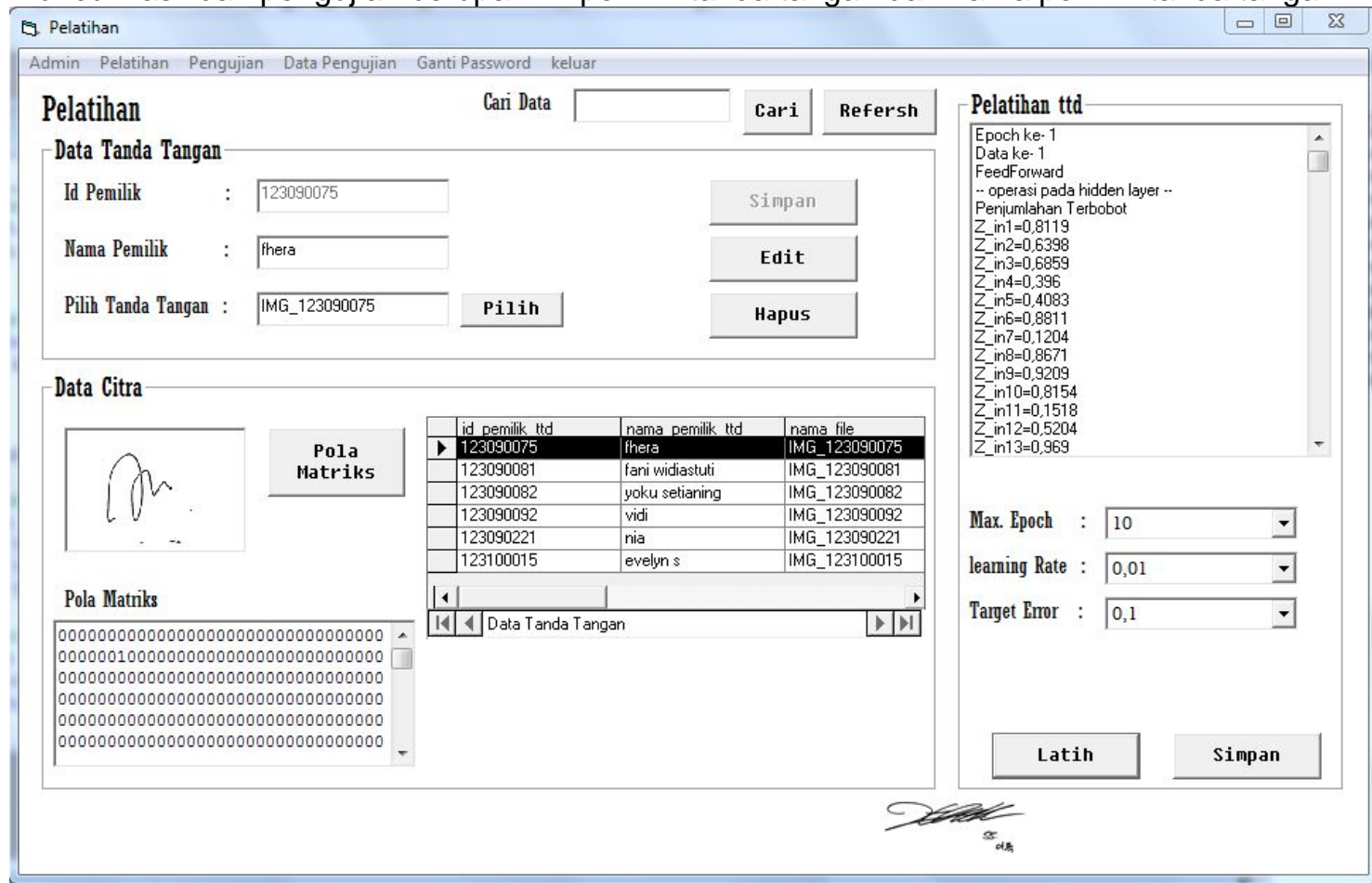

Gambar 4.2 Halaman Pengujian 


\subsection{Hasil Pengujian}

1. Data yang Dilatihkan

Pengujian dilakukan terhadap data tanda tangan yang telah dilatihkan sebelumnya. Terdapat 50 tanda tangan yang berasal dari 10 responden, di mana setiap responden diambil 5 sample tanda tangan., Hasil pengenalan terhadap tanda-tangan yang telah dilatihkan dapat dilihat pada Tabel 4.1 dan Tabel 4.2

Tabel 4.1. Tabel Hasil Pengujian Tanda Tangan yang Telah Dilatih

\begin{tabular}{|c|c|c|c|c|c|}
\hline \multirow{2}{*}{ No } & \multirow{2}{*}{ Nama Responden } & \multicolumn{2}{|c|}{ Konvergen } & \multirow{2}{*}{ Perhitungan } & \multirow{2}{*}{ Persentase } \\
\hline & & Benar & Salah & & \\
\hline 1 & Cahyo Budi & 4 & 1 & $\frac{\sum \text { Data Benar }}{\sum \text { Jumiah Data }} \times 100 \%=\frac{4}{5} \times 100 \%$ & $80 \%$ \\
\hline 2 & Elly Astuti Fera R & 3 & 2 & $\frac{\text { DData Benar }}{\text { DJumlah Data }} \times 100 \%=\frac{3}{5} \times 100 \%$ & $60 \%$ \\
\hline
\end{tabular}

Tabel 4.2. Lanjutan Tabel Hasil Pengujian Tanda Tangan yang Telah Dilatih

\begin{tabular}{|c|c|c|c|c|c|}
\hline \multirow{2}{*}{ No } & \multirow{2}{*}{ Nama Responden } & \multicolumn{2}{|c|}{ Konvergen } & \multirow{2}{*}{ Perhitungan } & \multirow{2}{*}{ Persentase } \\
\hline & & Benar & Salah & & \\
\hline 3 & Evelyn Sevina H & 5 & 0 & $\frac{\text { Doata Benar }}{\text { EJumlah Data }} \times 100 \%=\frac{5}{5} \times 100 \%$ & $100 \%$ \\
\hline 4 & Fani Widiastuti & 5 & 0 & $\frac{\sum \text { Data Benar }}{\sum \text { Jumlah Data }} \times 100 \%=\frac{5}{5} \times 100 \%$ & $100 \%$ \\
\hline 5 & Fitri Tristania G & 5 & 0 & $\frac{\sum \text { Dota Benar }}{\sum \text { JumlahData }} \times 100 \%=\frac{5}{5} \times 100 \%$ & $100 \%$ \\
\hline 6 & Galih Bayu S & 4 & 1 & $\frac{\text { DData Benar }}{\sum \text { Jumiah Data }} \times 100 \%=\frac{4}{5} \times 100 \%$ & $80 \%$ \\
\hline 7 & Nyimas R.A & 3 & 2 & $\frac{\sum \text { DotaBenar }}{\sum J \text { whlahData }} \times 100 \%=\frac{5}{5} \times 100 \%$ & $60 \%$ \\
\hline 8 & Vincentius Setyo K & 4 & 1 & $\frac{\text { Data Benar }}{\text { DJumlah Data }} \times 100 \%=\frac{4}{5} \times 100 \%$ & $80 \%$ \\
\hline 9 & Vidi Heri K & 4 & 1 & $\frac{\text { DData Bonar }}{\text { EJumiah Data }} \times 100 \%=\frac{4}{5} \times 100 \%$ & $80 \%$ \\
\hline 10 & Yoku Setianing S & 5 & 5 & $\frac{\sum \text { Data Benar }}{\sum 7 \text { umlah Data }} \times 100 \%=\frac{5}{5} \times 100 \%$ & $100 \%$ \\
\hline
\end{tabular}

Berdasarkan tabel 4.1 dan 4.2 terlihat bahwa sistem memiliki tingkat keberhasilan sebesar $\frac{\text { E Presmiase }}{\text { Eumlah responden }} \times 100 \%=\frac{340}{10} \times 100 \%=84 \%$ untuk mengenali tanda tangan seseorang yang telah dilatihkan.

2. Data yang tidak dilatihkan

Pengujian dilakukan terhadap data tanda tangan yang belum dilatihkan sebelumnya. Terdapat 30 tanda tangan yang berasal dari 10 responden, di mana setiap responden diambil 3 sample tanda tangan., Hasil pengenalan terhadap tanda-tangan yang belum dilatihkan dapat dilihat pada Tabel 4.3 dan 4.4

Tabel 4.3. Tabel Hasil Pengujian Tanda Tangan yang Belum Dilatih

\begin{tabular}{|c|l|c|c|c|c|}
\hline \multirow{2}{*}{ No } & \multirow{2}{*}{ Nama Responden } & \multicolumn{2}{|c|}{ Konvergen } & \multirow{2}{*}{ Perhitungan } & \multirow{2}{*}{ Persentase } \\
\cline { 3 - 4 } & & Benar & Salah & & \\
\hline 1 & Cahyo Budi & 2 & 1 & $\frac{\sum \text { Data Bonar }}{\text { Djumbiah Data }} \times 100 \%=\frac{2}{3} \times 100 \%$ & $66,6 \%$ \\
\hline
\end{tabular}


Tabel 4.4. Lanjutan Tabel Hasil Pengujian Tanda Tangan yang Belum Dilatih

\begin{tabular}{|c|c|c|c|c|c|}
\hline \multirow{2}{*}{ No } & \multirow{2}{*}{ Nama Responden } & \multicolumn{2}{|c|}{ Konvergen } & \multirow{2}{*}{ Perhitungan } & \multirow{2}{*}{ Persentase } \\
\hline & & Benar & Salah & & \\
\hline 2 & Elly Astuti Fera R & 2 & 1 & $\frac{\text { EData Benar }}{\sum \text { Jumlah Data }} \times 100 \%=\frac{2}{3} \times 100 \%$ & $66,6 \%$ \\
\hline 3 & Evelyn Sevina H & 3 & 0 & $\frac{\sum \text { Data Benar }}{\sum \text { Jumiah Data }} \times 100 \%=\frac{3}{3} \times 100 \%$ & $100 \%$ \\
\hline 4 & Fani Widiastuti & 3 & 0 & $\frac{\text { DData Eemar }}{\text { DJumiah Data }} \times 100 \%=\frac{3}{3} \times 100 \%$ & $100 \%$ \\
\hline 5 & Fitri Tristania G & 3 & 0 & $\frac{\text { VData Benar }}{\text { VJumlah Data }} \times 100 \%=\frac{5}{3} \times 100 \%$ & $100 \%$ \\
\hline 6 & Galih Bayu S & 2 & 1 & $\frac{\text { DData Benar }}{\text { EJumiah Data }} \times 100 \%=\frac{2}{\mathrm{~g}} \times 100 \%$ & $66,6 \%$ \\
\hline 7 & Nyimas R.A & 3 & 0 & $\frac{\sum \text { Data Benar }}{\sum \text { Jumlah Data }} \times 100 \%=\frac{3}{3} \times 100 \%$ & $100 \%$ \\
\hline 8 & Vincentius Setyo K & 3 & 0 & $\frac{\sum \text { Data Benar }}{\sum \text { Jumlah Data }} \times 100 \%=\frac{3}{3} \times 100 \%$ & $100 \%$ \\
\hline 9 & Vidi Heri K & 2 & 1 & $\frac{\sum \text { Data Benar }}{\text { DJumihh Data }} \times 100 \%=\frac{2}{3} \times 100 \%$ & $66,6 \%$ \\
\hline 10 & Yoku Setianing S & 3 & 0 & $\frac{\text { DData Benar }}{\text { DJumlah Data }} \times 100 \%=\frac{3}{3} \times 100 \%$ & $100 \%$ \\
\hline
\end{tabular}

Berdasarkan tabel 4.3 dan 4.4 terlihat bahwa sistem memiliki tingkat keberhasilan sebesar $\frac{\text { EPresentase }}{\text { Ejumah raponden }} \times 100 \%=\frac{866,4}{10} \times 100 \%=86,64 \%$ untuk mengenali tanda tangan seseorang yang telah dilatihkan.

\section{KESIMPULAN}

Dari hasil penelitian tugas akhir ini dapat ditarik kesimpulan telah dibangunnya sebuah Jaringan Saraf Tiruan Backpropagation untuk Aplikasi Pengenalan Tanda Tangan. Aplikasi ini mampu menganalisa karakteristik tanda tangan sehingga mempermudah dalam mengidentifikasi tanda tangan seseorang, walaupun hasilnya belum bisa $100 \%$ benar. Kesalahan dalam identifikasi tanda tangan terjadi karena beberapa hal, yaitu : posisi tanda tangan, file gambar yang rusak, dan proses pembelajaran yang belum maksimal.

\section{DAFTAR PUSTAKA}

Abbas, R. 1994, A Prototype System for off-line Signature Verificationusing Multilayered Feedforword Neural Networks, Tesis Departemen of Computer Science, RMIT.

Alan B. Sterneckert, 2003, Critical Incident Management, Auerbach Publications

Fausett, L., 1994, Fundamental of Neural Network architecture, Algorithms, and Applications, Prentice-Hall, USA.

Hermawan, Arif, 2006, Jaringan Saraf Tiruan (Teori dan Aplikasi), C.V Andi offset, Yogyakarta Jong, J.S, 2006, Jaringan Syaraf Tiruan dan Pemrogramannya Menggunakan Matlab, C.V Andi offset, Yogyakarta

Kusumadewi, S. , 2003, Artificial Intelligenci (Teknik dan Aplikasinya)/Sri Kusumadewi. - Edisi Pertama, Graha Ilmu, Yogyakarta

Kusumadewi, S. , 2004, Membangun Jaringan Saraf Tiruan Menggunakan MATLAB \& EXCEL LINK, Graha Ilmu, Yogyakarta.

Martin Fowler, 1997, UML Distilled: A Brief Guide to the Standard Object Modeling Language.

Oetomo, B.S.D, 2002, Perencanaan \& Pembangunan Sistem Informasi, Penerbit Andi, Yogyakarta.

Schmuller, Joseph, 1999, Teach Yourself UML in 24 Hours, Sams Publishing. 